\title{
Teaching Creative Writing Skills in the Class Room Challenges and Strategies \\ S. Mohan
}

\begin{abstract}
Creative writing can be defined as "the ability to harness creative thoughts revolving inside one's head and mind and put it into writing using very good sentence structure".The most important skill of any language is writing skill. It is the power students need to understand and control their lives, to shape their future, to define their hopes, dreams and aspirations. Writing allows students to put their ideas on a page. Anyone who thinks clearly should be able to write clearly -about anything in the world. Writing builds confidence and is not simply a way for students to demonstrate what they know. The essential thing is that everyone should be creative in his writing and should be unique. Creative writing is not confined to only writers, but is nowadays considered as a basic skill for getting success in life. We live in new world of teaching and learning. It's the world dominated with one clear aim of clearing 'the writing test'. But academicians should go beyond this only aim. And the prerequisite for the same is the belief that creative writing can be thought. The journey of teaching creative writing can be frustrating many times, but can also be rewarding sometimes. Definitely, if learning to write creatively is difficult, and then teaching to write creatively is equally difficult. By teaching students how to write well, by guiding them to focus their intellectual energy in this innovative way, a teacher can provide students a key that helps them unlock the complex ideas we expect them to a master as they mature. This can also contribute to the improvement in their behavior and self-esteem.
\end{abstract}

Keywords : creative writing, motivation, students ability, strategies.

\section{INTRODUCTION}

What Is Creative Writing?

According to Gaffield-Vile (1998), “creative writing is a journey of self-discovery prompts effective learning". Creative writing is an art of sorts - the art of making things up. According to chamber's dictionary, it may be defined as "having the power to create an imaginative, original literary production or composition". Creative writing is indeed a way to unlock creative potential, to foster students' love of language and to offer a powerful outlet for self-expression. Creative writing a form of artistic expression draws on the imagination to convey meaning through the use of imagery, fiction, drama and poetry.

Often a question arises in the mind of every English teacher before she begins the teaching of creative writing. The question is "whether creative writing can be taught successfully by me?" Well the answer for the same is that

Revised Manuscript Received on December 24, 2019

S.Mohan*, Department of English, Kalasalingam Academy of Research and Education, Krishnankoil, India. Email: smoha001 @ gmail.com creative writing cannot be taught but writers can be only motivated and inspired to write. Indeed after learning creative writing in the classroom, students develop creative attitude towards life too. This can help them to lead a better life and tackle the challenges of their personal and professional lives, as well. Creative writing can provide glory to a student in education and even in the world of work that follows.

Creative writing is the selection of appropriate words. Creative writing is not confined to novels, stories, and poems, simple email writing can also be creative. With the advancement in the technology and modes of communication, one can be creative even in blog drafting.

\section{CHALLENGES IN TEACHING CREATIVE WRITING SKILLS IN THE CLASSROOM:}

Despite the importance of writing skills, it is the most neglected part in the education process. Creative writing is a way to put your knowledge on a piece of paper/ screen in a novel way. It is not simply copying and memorizing. Although some students get success in learning creative writing skills, others experience frustration when attempt to write because of many challenges. Some of the challenges are:

- Absence of passion: though creativity is gift given by god, only a person with passion can achieve success in learning creative writing skills. Actually people are creative because they choose to be, so finding out about and encouraging students own interest is a good beginning.

- Mechanical aspects of writing: The students' fluency in generating creative piece of text is limited until they master the mechanical aspects of handwriting, spelling and grammar. Knowledge of punctuation, correct grammar, cohesive links within a paragraph and organization of text is essential for successful writing.

- Lack of confidence / Apprehension: Students have a fear factor and they often lack confidence. Creative writing is subject to criticism and sometimes it can be disrespectful. At other times it can be constructive also. A bare page can terrify the students and they are scared of the judgmental nature of others.

- How to starts with: 'what to write about?' is a common problem. The most difficult thing for a student concerning writing is to get started with the entire writing process. They never understand on which they will be able to write the best.

- Large size of the class: classrooms are over-crowded. With the strength of more than 70 students, it is a challenge for a teacher to give individual attention and feedback to the students. 
- Limitation of time: writing is the prisoner of time. With the limited duration of time, teachers find it complex to teach a challenging thing like creative writing. Writing proficiency can develop only with time. Effective teaching of creative writing consumes time. Time is taken for practice, to share writing, to respond and to evaluate.

- Lack of reading practice: although reading and writing are complementary skills they do not go hand in hand. Students of present generation do not like reading. They lack in reading skills.

\section{STRATEGIES TO OVERCOME THE CHALLENGES TO CREATIVE WRITING:}

To develop fluency in writing has always been a fundamental aim of education. Creative writing is a play of mind. It can be taught efficiently if the learners have some talent and passion for it. Students must be realized that they should think of an empty page as an open space. A good student writer can shape a whole world into that space. Creative writing can be nurtured among students by implementing strategies as follows:

- Providing creative environment and inviting classroom: Students should be motivated for brain-storming, mind mapping. The brainstorming techniques are designed to expand the cognitive toolkit students have in their brain. By thinking about a question from different perspectives of their classmates, students can develop the skills to react in broader range.

- Providing creative teaching methodologies: methodologies such as learning by doing, complementing each other should be adopted by teachers. Untrained teachers should be provided with right training and refresher courses from time to time. Creative teachers use blend of methods and activities which have creative dimension. Guided writing strategies by introducing jigsaw puzzles, storytelling can be helpful. Even independent writing strategies like providing students pictures of certain events and then inspiring them to complete the whole event can also be valuable. Asking open-ended questions and praising students who provide unexpected answers can also motivate the students.

- Building self-confidence: it is essential for a teacher to build confidence among the students. She can motivate student to write about anything of his choice. E.g. a letter to his favourite person, poem, and one-act play etc. group activities for writing can help remove anxiety and build confidence.

- Making time to write: writing should be introduced across the curriculum. Repeated practice sessions for improvement are essential.

- Size of the class: The crowd of the class should be decreased. Small group can get individual attention and best results. They can interact more and get individual feedback.

- Teacher as a role-model and motivator: A teacher of creative writing skills should write everyday along with students. She herself should be a model for students to inspire them. She can ask other students to read her writings and even comment on them. Teacher can establish an e-mail dialogue with the students for the same. Blog writing has proved a boon for the same. A teacher must motivate and inspire the students to write. They can just express their sorrows, happiness and feelings through writing.

- Assessing/providing constructive feedback: monitoring students' progress is essential. Feedback provided should be positive and constructive. As red ink sea of circles, cross cuts, underlines and worst ever question marks can only hurt the ego of the students. Creative writing assessment must support growth and growth takes time. Moreover the feedback should not only be about the spellings, punctuation and grammar. The content of creative writing is far more than the mechanics part of writing.

- Read, read and read with writer's eye: it is necessary to be critical reader to be creative writer. Promote reading among students by giving books of great writers. Use of newspapers, biographies of great and famous persons can be introduced to encourage them.

\section{CONCLUSION:}

Teachers should focus on teaching creative writing in English language as a process and not as a product. This process of writing is rewarding. It can revive students from depression to happiness. Instead of teacher centred, the learning should be learner centred. So that students should think creatively and critically. This will help them to solve the problems and live a better life. By teaching students how to write well, we can unlock the talent and hidden potential of the students. And everyone must remember that to teach creative writing skills is every teacher's responsibility and not only an English teacher's responsibility. To teach creative writing is to go through a long journey from mind to matter.

\section{REFERENCES}

1. Bhatia,V.K.(1993).Analyzing Genre: Language use in

2. professional settings. London, Longman.

3. Clementson, T.(2005) .Natural English Writing \& reading Skills. China: Oxford University Press.

\section{AUTHORS PROFILE}

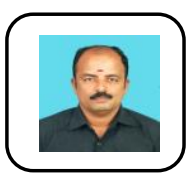

Dr. S. Mohan is an Associate Professor of the English Department at Kalasalingam Academy of Research and Education, Krishnankoil, Tamilnadu, India and is serving as Associate and Editorial Board member in more than eight International Journals. His areas of interest and research are in World Literatures, English Language Teaching and his main research area is African American Literature, which he formalized in his $\mathrm{PhD}$ (2013) on this subject. He has taught British, American, Indian Literatures and Literary Criticism in Post Graduate and Pre Doctoral Degree. He also taught Communicative English, English for Technical Communication for engineering graduates. He has presented papers at conferences, published articles and papers in various International journals. He has produced more than 25 M.Phil scholars and $04 \mathrm{PhD}$ scholars are pursuing their research under his guidance.. 